\title{
Design of a Reliable Hybrid (PV/Diesel) Power System with Energy Storage in Batteries for Remote Residential Home
}

\author{
Vincent Anayochukwu Ani \\ Department of Electronic Engineering, University of Nigeria, Nsukka 410001, Nigeria \\ Correspondence should be addressed to Vincent Anayochukwu Ani; vincent_ani@yahoo.com
}

Received 17 March 2016; Accepted 26 May 2016

Academic Editor: Mohamed Benghanem

Copyright ( 2016 Vincent Anayochukwu Ani. This is an open access article distributed under the Creative Commons Attribution License, which permits unrestricted use, distribution, and reproduction in any medium, provided the original work is properly cited.

\begin{abstract}
This paper reports the experience acquired with a photovoltaic (PV) hybrid system simulated as an alternative to diesel system for a residential home located in Southern Nigeria. The hybrid system was designed to overcome the problem of climate change, to ensure a reliable supply without interruption, and to improve the overall system efficiency (by the integration of the battery bank). The system design philosophy was to maximize simplicity; hence, the system was sized using conventional simulation tool and representative insolation data. The system includes a $15 \mathrm{~kW} \mathrm{PV}$ array, $21.6 \mathrm{kWh}(3600 \mathrm{Ah})$ worth of battery storage, and a $5.4 \mathrm{~kW}$ $(6.8 \mathrm{kVA})$ generator. The paper features a detailed analysis of the energy flows through the system and quantifies all losses caused by PV charge controller, battery storage round-trip, rectifier, and inverter conversions. In addition, simulation was run to compare $\mathrm{PV} /$ diesel/battery with diesel/battery and the results show that the capital cost of a PV/diesel hybrid solution with batteries is nearly three times higher than that of a generator and battery combination, but the net present cost, representing cost over the lifetime of the system, is less than one-half of the generator and battery combination.
\end{abstract}

\section{Introduction}

Energy is essential to economic and social development and improves quality of life. It is very important for the developing society [1]. In Nigeria, most residential homes are connected to the electric grid. However, there still exist several "off-grid" or remote locations, which, for financial and/or environmental reasons related to their distance from an existing power line, are not connected to the utility grid. Most of these residences derive their electricity from gasoline or diesel powered generators, which can be noisy and have the disadvantage of increasing the greenhouse gas emission which has a negative impact on the environment. Amid the environmental problems of using petrol and diesel generators, the cost of running them is quite high. Due to the high cost of running petrol/diesel generators, many Nigerians are willing to shift from using these traditional generators to the use of renewable energy technologies.

Renewable energy technologies (such as solar-photovoltaic systems) can be localized and decentralized unlike the national electricity grid. This allows end-users to generate their own electricity wherever they are located. Also, the technologies do not require any running cost, unlike the traditional petrol/diesel generators.

The installation of a solar power system to replace or offset a portion of the diesel electricity generation is an option to consider for remote residential homes. A complete replacement of diesel generation with solar power is usually not feasible, due to low solar input during the rainy season. However, a solar/diesel combination system known as hybrid system can prove to be very reliable and cost effective given the right conditions (such as optimal sizing). Hybrid energy applications are of increasing interest, and a well-managed hybrid solardiesel system can achieve lifetime fuel savings, while ensuring reliable electricity supply. Insofar as diesel fuel is reduced, and such systems reduce $\mathrm{CO}_{2}$ as well as particulate emissions that are harmful to health. They are an economical option in areas isolated from the grid.

This paper describes the way to design the aspects of a hybrid power system, a photovoltaic (PV) generator with energy storage for a residential use. The decision to select a PV generator hybrid system rather than a pure PV system for 
TABLE 1: Energy needed for the household use.

\begin{tabular}{|c|c|c|c|c|c|}
\hline Description of item & $\begin{array}{c}\text { Item } \\
\text { abbreviation }\end{array}$ & $\begin{array}{c}\text { Power rating } \\
\text { (watts) }\end{array}$ & Qty & $\begin{array}{c}\text { Total load } \\
\text { (watts) }\end{array}$ & Daily hour of actual utilization (hr. per day) \\
\hline Medium size deep-freezer & $\mathrm{DF}$ & 130 & 1 & 130 & $24 \mathrm{~h}(00: 00 \mathrm{~h}-24: 00 \mathrm{~h})$ \\
\hline Water pumping machine & PM & 1000 & 1 & 1000 & $1 \mathrm{~h}(13: 00 \mathrm{~h}-14: 00 \mathrm{~h})$ \\
\hline Washing machine & WM & 280 & 1 & 280 & $1 \mathrm{~h}(09: 00 \mathrm{~h}-10: 00 \mathrm{~h})$ \\
\hline Electric stove & ES & 1000 & 1 & 1000 & $2 \mathrm{~h}(17: 00 \mathrm{~h}-19: 00 \mathrm{~h})$ \\
\hline Microwave oven & $\mathrm{MO}$ & 1000 & 1 & 1000 & $2 \mathrm{~h}(06: 00 \mathrm{~h}-07: 00 \mathrm{~h} ; 11: 00 \mathrm{~h}-12: 00 \mathrm{~h})$ \\
\hline Electric pressing iron & PI & 1000 & 1 & 1000 & $1 \mathrm{~h}(12: 00 \mathrm{~h}-13: 00 \mathrm{~h})$ \\
\hline Air-conditioner & $\mathrm{AC}$ & 1170 & 1 & 1170 & $9 \mathrm{~h}(08: 00 \mathrm{~h}-17: 00 \mathrm{~h})$ \\
\hline Refrigerator & $\mathrm{RF}$ & 500 & 1 & 500 & $9 \mathrm{~h}(08: 00 \mathrm{~h}-17: 00 \mathrm{~h})$ \\
\hline Water bath & WB & 1000 & 1 & 1000 & $2 \mathrm{~h}(03: 00 \mathrm{~h}-04: 00 \mathrm{~h} ; 18: 00 \mathrm{~h}-19: 00 \mathrm{~h})$ \\
\hline Ceiling fan & $\mathrm{CF}$ & 100 & 14 & 1400 & $14 \mathrm{~h}(08: 00 \mathrm{~h}-22: 00 \mathrm{~h})$ \\
\hline Energy efficient lighting & EL & 6 & 23 & 138 & $8 \mathrm{~h}(04: 00 \mathrm{~h}-08: 00 \mathrm{~h} ; 18: 00 \mathrm{~h}-22: 00 \mathrm{~h})$ \\
\hline Lighting-outdoor (security) & LO & 9 & 4 & 36 & $13 \mathrm{~h}(18: 00 \mathrm{~h}-07: 00 \mathrm{~h})$ \\
\hline $21^{\prime \prime}$ TV with decoder & $21^{\prime \prime} \mathrm{TV}-\mathrm{D}$ & 150 & 1 & 150 & $9 \mathrm{~h}(08: 00 \mathrm{~h}-17: 00 \mathrm{~h})$ \\
\hline $21^{\prime \prime}$ television & $21^{\prime \prime} \mathrm{TV}$ & 100 & 1 & 100 & $11 \mathrm{~h}(18: 00 \mathrm{~h}-05: 00 \mathrm{~h})$ \\
\hline $14^{\prime \prime}$ television & $14^{\prime \prime} \mathrm{TV}$ & 80 & 8 & 640 & $22 \mathrm{~h}(06: 00 \mathrm{~h}-17: 00 \mathrm{~h} ; 18: 00 \mathrm{~h}-05: 00 \mathrm{~h})$ \\
\hline Sony music system & SM & 100 & 1 & 100 & $1 \mathrm{~h}(04: 00 \mathrm{~h}-05: 00 \mathrm{~h})$ \\
\hline DSTV receiver & $\mathrm{D}-\mathrm{R}$ & 50 & 1 & 50 & $22 \mathrm{~h}(06: 00 \mathrm{~h}-17: 00 \mathrm{~h} ; 18: 00 \mathrm{~h}-05: 00 \mathrm{~h})$ \\
\hline DVD player & $\mathrm{D}-\mathrm{P}$ & 50 & 1 & 50 & $2 \mathrm{~h}(19: 00 \mathrm{~h}-21: 00 \mathrm{~h})$ \\
\hline Computer printer & $\mathrm{CP}$ & 100 & 1 & 100 & $1 \mathrm{~h}(15: 00 \mathrm{~h}-16: 00 \mathrm{~h})$ \\
\hline Computer PC & $\mathrm{PC}$ & 115 & 1 & 115 & $9 \mathrm{~h}(08: 00 \mathrm{~h}-17: 00 \mathrm{~h})$ \\
\hline Computer laptop & $\mathrm{CL}$ & 35 & 1 & 35 & $9 \mathrm{~h}(08: 00 \mathrm{~h}-17: 00 \mathrm{~h})$ \\
\hline Miscellaneous & M & 100 & 1 & 100 & $24 \mathrm{~h}(00: 00 \mathrm{~h}-24: 00 \mathrm{~h})$ \\
\hline
\end{tabular}

the considered location is consistent with its solar irradiation. This system will replace an existing diesel powered electric generator and was sized to meet the residence's known lighting and plug loads, refrigeration, cooking, and heating needs. The residence is located about a $\mathrm{km}$ from the utility grid and the location is characterized by a yearly global irradiation of about $2150 \mathrm{kWh} / \mathrm{m}^{2}$. Also, this study is to produce a detailed experimental accounting of energy flows through the hybrid system and quantify all system losses. In addition, the hybrid system designed will be compared with the diesel/battery system in terms of costs and environmental impacts.

(1) Description of the Residential Home. The residence is a duplex building and has six rooms, a kitchen, and a sitting room at the ground floor, while it has three masters' rooms, a library, and a small sitting room upstairs. The building is furnished with electric power consumptions such as washing machine, electric stove, electric pressing iron, DVD, stereo cassette, television, decoder/cable, water pumping machine, fans, electric bulbs, water bath, deep-freezer, and microwave. Each room has fan, electric bulb, and television. The sitting room at the upstairs uses air-condition, while the one at the ground floor uses four fans. The residence is not connected to the grid and currently utilizes a diesel power generating system to meet its energy needs.
In this research, load assessment and the pattern of using electricity power within the house were carried out based on data provided by the occupant of the house and a site visit to evaluate the characteristics of the power system, power requirements, and power system management and operation. The daily power demands for the residential home are tabulated in Tables 1 and 2 and shown in Figure 1. These tables show the estimation of each appliance's rated power, its quantity, and the hours of use by the residence in a single day. The miscellaneous load is for unknown loads in the house.

(2) Overview of the Study Area. This research focuses on the design of a hybrid power system with energy storage in batteries for a residential home. The residential home where the study was done is located in a remote setting of Ndiagu-Akpugo. Ogologo-Eji Ndiagu-Akpugo is in NkanuWest LGA of Enugu State in South-Eastern Nigeria on latitude $6^{\circ} 35^{\prime} \mathrm{N}$ and longitude $7^{\circ} 51^{\prime} \mathrm{E}$. The data for solar resource (used in generating Figure 2) were obtained from the National Aeronautics and Space Administration (NASA) Surface Meteorology and Solar Energy web site [2]. After scaling on this data, the scaled annual average resource of $4.7 \mathrm{kWh} / \mathrm{m}^{2} / \mathrm{d}$ was obtained for the site. As can be seen in Figure 2 , months below $4.5 \mathrm{kWh} / \mathrm{m}^{2} / \mathrm{d}$ are the months of June, July, August, and September which are the months of raining season in Nigeria, and there are likely to be more cloudy days on these months. 


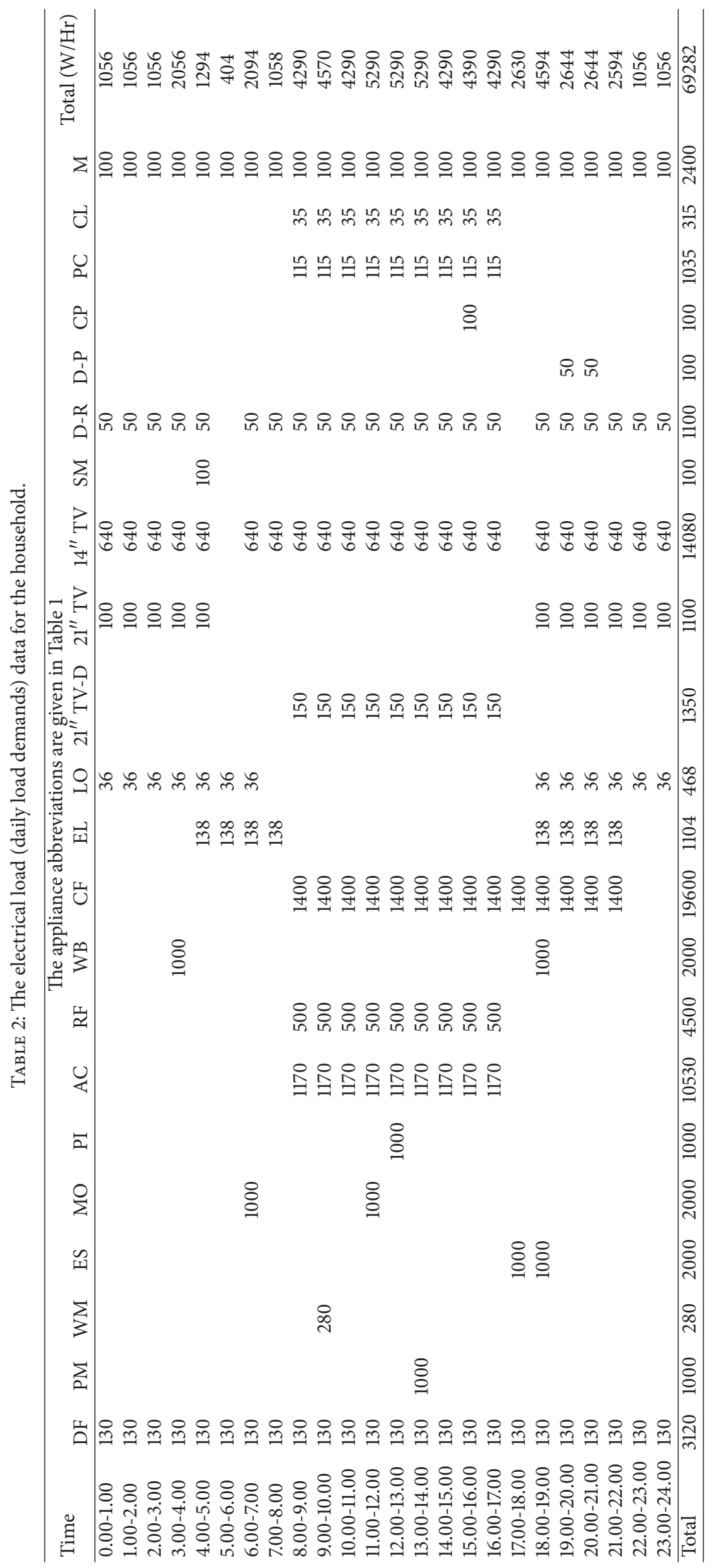




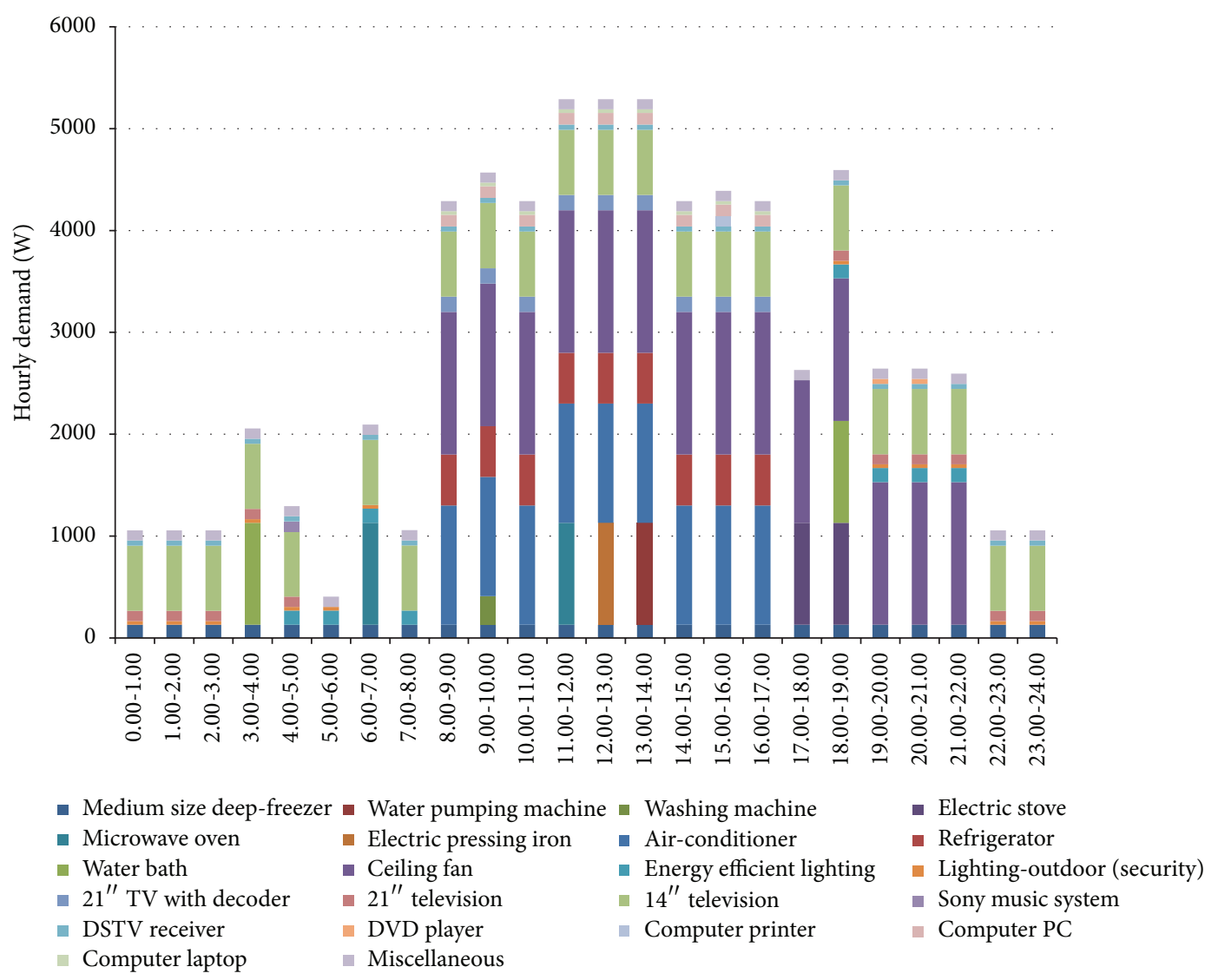

FIgURE 1: Hourly power demand profile of the household.

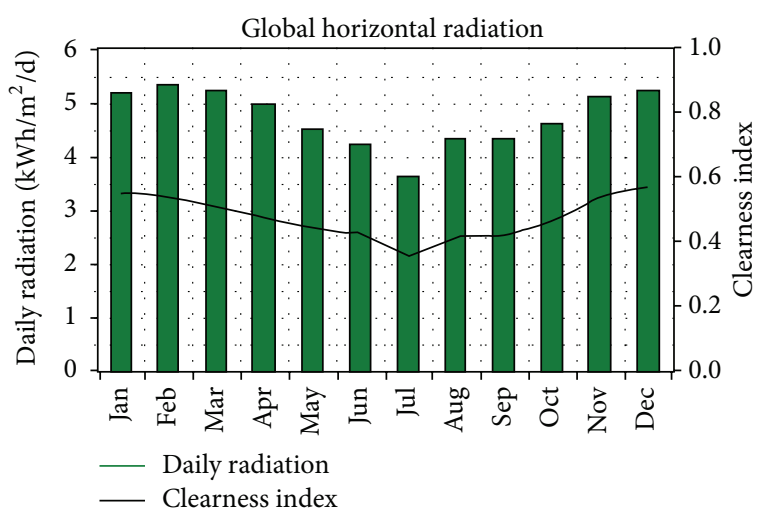

FIgURE 2: Solar daily radiation profile for Ndiagu-Akpugo in NkanuWest (Enugu State) [2].

\section{Energy Models}

Energy model depends mainly on the economic feasibility and the proper sizing of the components in order to avoid outages as well as ensuring quality and reliability of supply. Energy design system looks into its sizing and the process of selecting the best components to provide cheap, efficient, reliable, environmentally friendly, and cost effective power supply [3]. The technoeconomic analysis looks at both environmental cost and the cheapest cost of energy produced by the system components. Designing a hybrid system would require correct components selection and sizing, with appropriate operation strategy $[4,5]$.

In energy systems, the sizing of the individual systems can be made in a variety of ways, depending upon the choice of parameters of interest. Energy models are employed as a supporting tool to develop energy strategies as well as outlining the likely future structure of the system under particular conditions. This helps to provide insights into the technological paths, structural evolution, and policies that should be followed [3]. A lot of research has been conducted on the performance of hybrid power systems and experimental results have been published in many articles [6-13]. The energy output of a hybrid system can be enough for the demands of a house placed in regions where the extension of the already available electricity grid would be financially unadvisable [9]. A method of sizing hybrid PV systems regarding the reliability to satisfy the load demand, economy of components, and discharge depth exploited by the batteries is therefore required.

Several models have been developed, simulating and sizing PV systems using different operation strategies. The estimation of performance of PV systems based on the Loss of Load Probability (LLP) technique is developed by [1417]. These analytical methods are simple to apply but they are not general. On the other hand, the numerical methods 
presented by [18-24] present a good solution, but these need a long period solar radiation data record. Other methods estimate the excess of energy provided by PV generators and the storage capacity of the batteries using the utilizability method [25].

The conventional methodology (empiric, analytic, and numeric) for sizing PV systems has been used for a location where the required weather data (irradiation, temperature, humidity, clearness index, etc.) and the information concerning the site where we want to implement the PV system are available. In this case these methods present a good solution for sizing PV systems. However, these techniques could not be used for sizing PV systems in remote areas, in the case where the required data are not available. Moreover, the majority of the above methods need the long term meteorological data such as total solar irradiation and air temperature for their operation. So, when the relevant meteorological data are not available, these methods cannot be used, especially in the isolated areas. In this context, a model was developed, and the methodology aims at finding the configuration, among a set of systems components, which meets the desired system reliability requirements, with the lowest value of levelised cost of energy (LCE). This methodology can be used for determining the optimum number of solar panels and batteries configurations (the storage capacity of the batteries necessary to satisfy a given consumption). Since the investigation of this paper is based on a detailed study of an analysis of the energy flows, the analysis reveals the energy losses (charge controller, rectifier, battery, and inverter) in the system and the storage requirement. In addition, the model developed was used to select the optimal sizing parameters of PV system in which the results obtained have been compared and tested with HOMER software.

\subsection{Development of a Model for Energy System Components.} Modelisation is an essential step before any phase of component sizing. Various modeling techniques are developed, to model hybrid PV/diesel system components, in previous studies. For a hybrid PV/diesel system with storage battery, three principal subsystems are included, the PV generator, the diesel generator, and the battery storage. A methodology for modeling hybrid PV/diesel system components is described below. The theoretical aspects are given below (Sections 2.1.1, 2.1.2, 2.1.3, 2.1.4 and 2.1.5) and are based on the works of Ani [3], Gupta et al. [26], and Ashok [27].

2.1.1. Modeling of Solar-Photovoltaic Generator. Using the solar radiation available, the hourly energy output of the PV generator $\left(E_{\mathrm{PVG}}\right)$ can be calculated according to the following equation $[3,27-29]$ :

$$
E_{\mathrm{PVG}}=G(t) \times A \times P \times \eta_{\mathrm{PVG}} .
$$

2.1.2. Modeling of Diesel Generator. Hourly energy generated by diesel generator $\left(E_{\mathrm{DEG}}\right)$ with rated power output $\left(P_{\mathrm{DEG}}\right)$ is defined by the following expression $[3,27,28]$ :

$$
E_{\mathrm{DEG}}(t)=P_{\mathrm{DEG}}(t) \times \eta_{\mathrm{DEG}} .
$$

2.1.3. Modeling of Converter. In the proposed scheme, a converter contains both rectifier and inverter. PV energy generator and battery subsystems are connected with DC bus while diesel generating unit subsystem is connected with $\mathrm{AC}$ bus. The electric loads connected in this scheme are AC loads.

The rectifier is used to transform the surplus AC power from the diesel electric generator to charge the battery. The diesel electric generator will be powering the load and at the same time charging the battery. The rectifier model is given below:

$$
\begin{aligned}
E_{\text {REC-OUT }}(t) & =E_{\text {REC-IN }}(t) \times \eta_{\text {REC }}, \\
E_{\text {REC-IN }}(t) & =E_{\text {SUR-AC }}(t) .
\end{aligned}
$$

At any time $t$,

$$
E_{\mathrm{SUR}-\mathrm{AC}}(t)=E_{\mathrm{DEG}}(t)-E_{\text {Load }}(t) .
$$

The inverter model for photovoltaic generator and battery bank are given below:

$$
\begin{aligned}
E_{\mathrm{PVG}-\mathrm{IN}}(t) & =E_{\mathrm{PVG}}(t) \times \eta_{\mathrm{INV}}, \\
E_{\mathrm{BAT}-\mathrm{INV}}(t) & =\left[\frac{\left(E_{\mathrm{BAT}}(t-1)-E_{\mathrm{LOAD}}(t)\right)}{\left(\eta_{\mathrm{INV}} \times \eta_{\mathrm{DCHG}}\right)}\right] .
\end{aligned}
$$

2.1.4. Modeling of Charge Controller. To prevent overcharging of a battery, a charge controller is used to sense when the batteries are fully charged and to stop or reduce the amount of energy flowing from the energy source to the batteries. The model of the charge controller is presented below:

$$
\begin{aligned}
E_{\mathrm{CC}-\mathrm{OUT}}(t) & =E_{\mathrm{CC}-\mathrm{IN}}(t) \times \eta_{\mathrm{CC}}, \\
E_{\mathrm{CC}-\mathrm{IN}}(t) & =E_{\text {REC-OUT }}(t)+E_{\text {SUR-DC }}(t) .
\end{aligned}
$$

2.1.5. Modeling of Battery Bank. The battery state of charge (SOC) is the cumulative sum of the daily charge/discharge transfers. The battery serves as an energy source entity when discharging and a load when charging. At any time, $t$, the state of battery is related to the previous state of charge and to the energy production and consumption situation of the system during the time from $t-1$ to $t$.

During the charging process, when the total output of all generators exceeds the load demand, the available battery bank capacity at time, $t$, can be described by $[3,29,30]$

$$
E_{\mathrm{BAT}}(t)=E_{\mathrm{BAT}}(t-1)-E_{\mathrm{CC} \text {-OUT }}(t) \times \eta_{\mathrm{CHG}} .
$$

On the other hand, when the load demand is greater than the available energy generated, the battery bank is in discharging state. Therefore, the available battery bank capacity at time, $t$, can be expressed as $[3,29]$

$$
E_{\mathrm{BAT}}(t)=E_{\mathrm{BAT}}(t-1)-E_{\text {Needed }}(t) .
$$

Let $d$ be the ratio of minimum allowable SOC voltage limit to the maximum $\mathrm{SOC}$ voltage across the battery terminals when it is fully charged. So, the depth of discharge (DOD) is

$$
\mathrm{DOD}=(1-d) \times 100 .
$$


DOD is a measure of how much energy has been withdrawn from a storage device, expressed as a percentage of full capacity. The maximum value of SOC is 1 , and the minimum SOC is determined by maximum depth of discharge (DOD):

$$
\mathrm{SOC}_{\mathrm{Min}}=1-\frac{\mathrm{DOD}}{100} \text {. }
$$

2.2. Mathematical Cost Model (Economic and Environmental Costs) of Energy Systems. This work developed a mathematical model of a system that could represent the integral (total sum) of the minimum economic and environmental (health and safety) costs of the considered options.

2.2.1. The Annualized Cost of a Component. The annualized cost of a component includes annualized capital cost, annualized replacement cost, annual O\&M cost, emissions cost, and annual fuel cost (generator). Operation cost is calculated hourly on daily basis $[3,27,29,31]$.

2.2.2. Annualized Capital Cost. The annualized capital cost of a system component is equal to the total initial capital cost multiplied by the capital recovery factor. Annualized capital cost is calculated using $[3,27,29,31]$

$$
C_{\text {acap }}=C_{\text {cap }} \cdot \operatorname{CRF}\left(i, R_{\text {proj }}\right) \text {. }
$$

2.2.3. Annualized Replacement Cost. The annualized replacement cost of a system component is the annualized value of all the replacement costs occurring throughout the lifetime of the project minus the salvage value at the end of the project lifetime. Annualized replacement cost is calculated using $[3,27,29,31]$

$$
C_{\text {arep }}=C_{\text {rep }} \cdot f_{\text {rep }} \cdot \operatorname{SFF}\left(i, R_{\text {comp }}\right)-S \cdot \operatorname{SFF}\left(i, R_{\text {proj }}\right) .
$$

$f_{\text {rep }}$, a factor arising because the component lifetime can be different from the project lifetime, is given by

$$
f_{\text {rep }}= \begin{cases}\frac{\operatorname{CRF}\left(i, R_{\text {proj }}\right)}{\operatorname{CRF}\left(i, R_{\text {rep }}\right)}, & R_{\text {rep }}>0, \\ 0, & R_{\text {rep }}=0 .\end{cases}
$$

$$
C_{\text {emissions }}=\frac{c_{\mathrm{CO}_{2}} M_{\mathrm{CO}_{2}}+c_{\mathrm{CO}} M_{\mathrm{CO}}+c_{\mathrm{UHC}} M_{\mathrm{UHC}}+c_{\mathrm{PM}} M_{\mathrm{PM}}+c_{\mathrm{SO}_{2}} M_{\mathrm{SO}_{2}}+c_{\mathrm{NO}_{x}} M_{\mathrm{NO}_{x}}}{1000}
$$

Total cost of a component $=$ economic cost + environmental cost, where economic cost $=$ capital cost + replacement cost + operation and maintenance cost + fuel cost (generator). Also environmental cost $=$ emissions cost.

Annualized Cost of a Component Is Calculated Using [3, $27,29,31]$

$$
C_{\text {ann }}=C_{\text {acap }}+C_{\text {arep }}+C_{\text {aop }}+C_{\text {emissions }} \text {. }
$$

$R_{\text {rep }}$, the replacement cost duration, is given by

$$
R_{\text {rep }}=R_{\text {comp }} \cdot \operatorname{INT}\left(\frac{R_{\text {proj }}}{R_{\text {comp }}}\right) \text {. }
$$

SFF(), the sinking fund factor which is a ratio used to calculate the future value of a series of equal annual cash flows, is given by

$$
\operatorname{SFF}(i, N)=\frac{i}{(1+i)^{N}-1}
$$

The salvaged value of the component at the end of the project lifetime is proportional to its remaining life. Therefore, the salvage value $S$ is given by

$$
S=C_{\text {rep }} \cdot \frac{R_{\text {rem }}}{R_{\text {comp }}} .
$$

$R_{\text {rem }}$, the remaining life of the component at the end of the project lifetime, is given by

$$
R_{\text {rem }}=R_{\text {comp }}-\left(R_{\text {proj }}-R_{\text {rep }}\right) \text {. }
$$

2.2.4. Annualized Operating Cost. The operating cost is the annualized value of all costs and revenues other than initial capital costs and is calculated using $[3,27,29,31]$

$$
C_{\mathrm{aop}}=\sum_{t=1}^{365}\left\{\sum_{t=1}^{24}\left[C_{\mathrm{oc}}(t)\right]\right\}
$$

2.2.5. Cost of Emissions. The following equation is used to calculate the cost of emissions [3, 27, 29, 31]:
Annualized Total Cost of a Component Is Calculated Using $[29,31]$

$$
C_{\text {ann }, \text { tot }, c}=\sum_{c=1}^{N_{c}}\left(C_{\text {acap }, c}+C_{\text {arep }, c}+C_{\text {aop }, c}+C_{\text {emissions }}\right) .
$$

From (21), the economic and environmental cost model through annualized total cost of different configurations of 
power system results in the hybridizing of the renewable energy generator (PV) with existing energy (diesel) is given below.

Economic and environmental cost model of running solar + diesel generator + batteries + converter is calculated as

$$
\begin{gathered}
C_{\mathrm{ann}, \mathrm{tot}, \mathrm{s}+\mathrm{g}+b+c}=\sum_{s=1}^{N_{s}}\left(C_{\mathrm{acap}, s}+C_{\mathrm{arep}, \mathrm{s}}+C_{\mathrm{aop}, s}\right. \\
\left.+C_{\text {emissions }}\right)+\sum_{g=1}^{N_{g}}\left(C_{\mathrm{acap}, \mathcal{g}}+C_{\mathrm{arep}, \mathcal{g}}+C_{\mathrm{aop}, g}\right. \\
\left.+C_{\text {emissions }}+C_{\mathrm{af}, g}\right)+\sum_{b=1}^{N_{b}}\left(C_{\mathrm{acap}, b}+C_{\mathrm{arep}, b}+C_{\mathrm{aop}, b}\right. \\
\left.+C_{\text {emissions }}\right)+\sum_{c=1}^{N_{c}}\left(C_{\mathrm{acap}, c}+C_{\mathrm{arep}, c}+C_{\mathrm{aop}, c}\right) .
\end{gathered}
$$

2.3. Description of the Computer Simulation. A computer program was developed and used to build the hybrid (PV/diesel) system model. Data inputs to the program are hourly load demand data, latitude, and longitude of the site and reference component cost. The designed software determines as its output the size of system components (sizing parameters) and the performance of the system over the course of the year (see the supplementary data in Supplementary Material available online at http://dx.doi.org/10.1155/2016/6278138) by showing the power supplied by each of the energy systems over the year, given the load conditions and taking into account the technical factors. The designed software can be used to study how the hybrid (PV/diesel) system is being supplied.

2.4. Validation of the Model. The designed software results were carried out followed with HOMER data to validate the analysis. The comparison shows a close agreement between results obtained from the designed software module and results obtained from HOMER setup. In addition, before using the measured data gotten from NASA datasets in simulating the individual components of a PV/diesel hybrid system, the developed program accuracy was established; the simulated data predicted by the software program fall within the bounds of the measured data. The algorithm that the developed program uses to synthesize solar data is based on the work of Graham and Hollands [32]. The realistic nature of synthetic data created by this algorithm is demonstrated and the test shows that synthetic solar data (simulated) produce virtually the same simulation results as real data (measured) as shown in Figure 3.

\section{System Description}

The designed system considered in this paper is a hybrid system which consists of a renewable (photovoltaic) energy system integrated in a conventional (diesel) power generation system, energy storage in battery, a DC/AC converter (an inverter for the conversion of generated $\mathrm{DC}$ power into

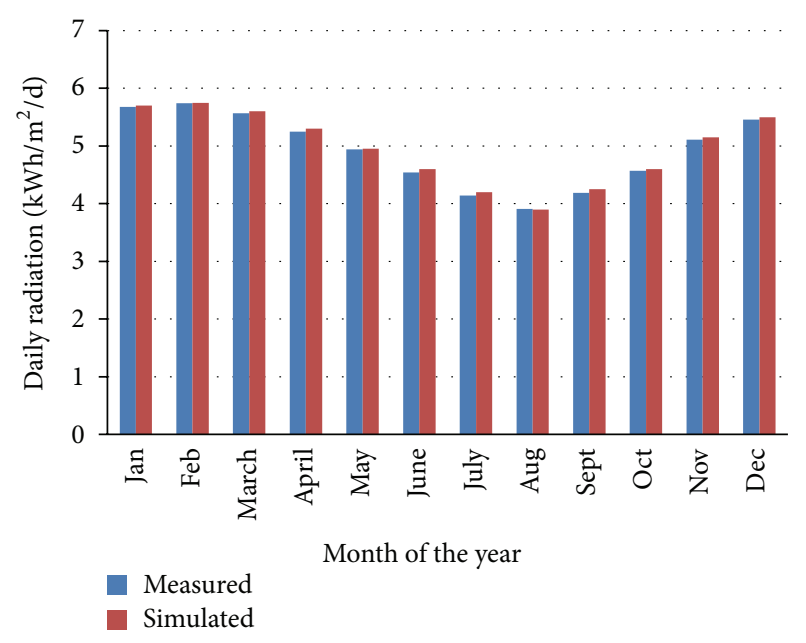

FIGURE 3: Calibrated solar radiation.

required $\mathrm{AC}$ power), and an $\mathrm{AC} / \mathrm{DC}$ converter (a rectifier for the conversion of generated $\mathrm{AC}$ power in order to charge the battery) as shown in Figure 4 . The inverter used is bidirectional, also known as power converter, which maintains energy flow between AC and DC components, since the flow comes in two different directions (from AC to DC and from $\mathrm{DC}$ to $\mathrm{AC})$.

The flow from the solar array passes through the charge controller to charge the battery and at the same time supply electricity to the load through the inverter. The actual AC power obtained after the conversion from a solar array can be seen in Table 3. The charge controller monitors and controls the charging and discharging of the battery in order not to allow the battery to be damaged (due to overcharging or overdischarging).

Another flow comes from diesel generator when the PV and the battery could no longer serve the load; the generator supplies electricity direct to serve the load and at the same time charge the battery through the rectifier. That is how the designed hybrid system is expected to work.

The system design was to be representative of the type of residential systems that were likely to be installed in the foreseeable future. Hence, the system was sized using conventional simulation tool and representative insolation data.

\subsection{Cost of Key Components (including Installation and Labour) and Interest Rate for Capital Investments}

3.1.1. PV System Cost (US\$ 2/Wp). The cost of PV panels on the Nigerian market was estimated as US\$ $0.600 / \mathrm{Wp}$ based on prices cited by Nigerian suppliers (based on the cost of a module of $1210 \times 808 \times 35 \mathrm{~mm}$ size generating 130 watts of peak power (Wp DC) in controlled conditions) [34]. This was adjusted upward to US\$2/Wp to account for other support components that are required, also known as balance of system (BOS) parts, such as cables, charge controller with maximum power point tracker, lightening protection, and delivery/labour and installation costs. 


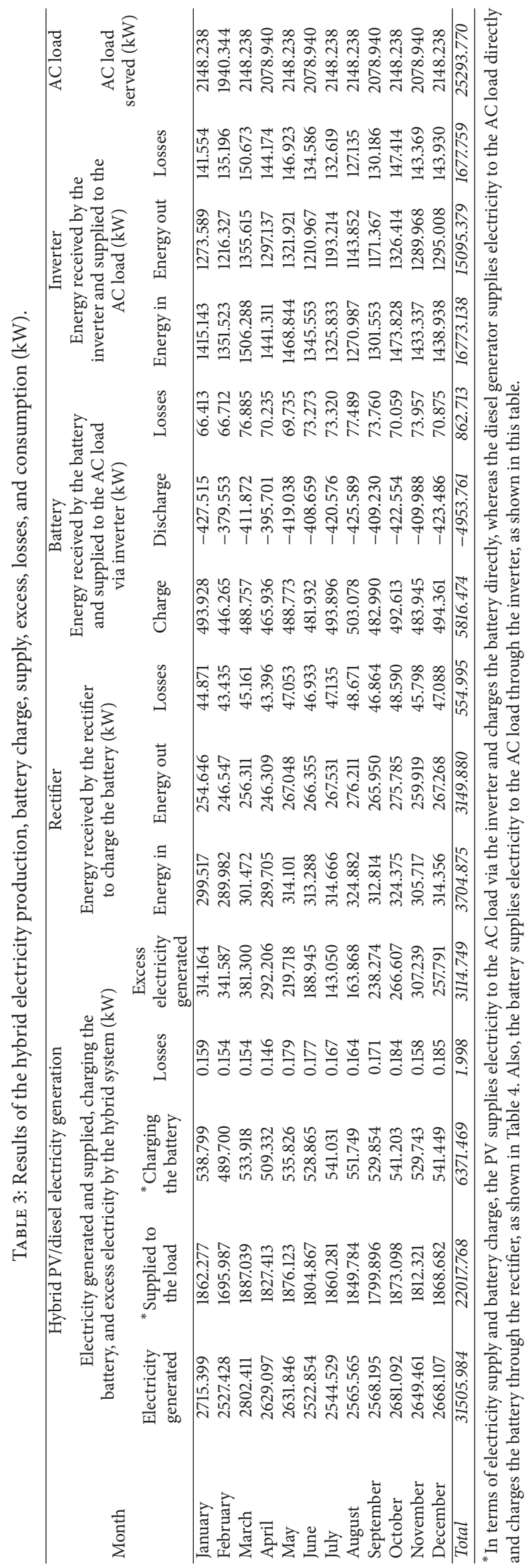




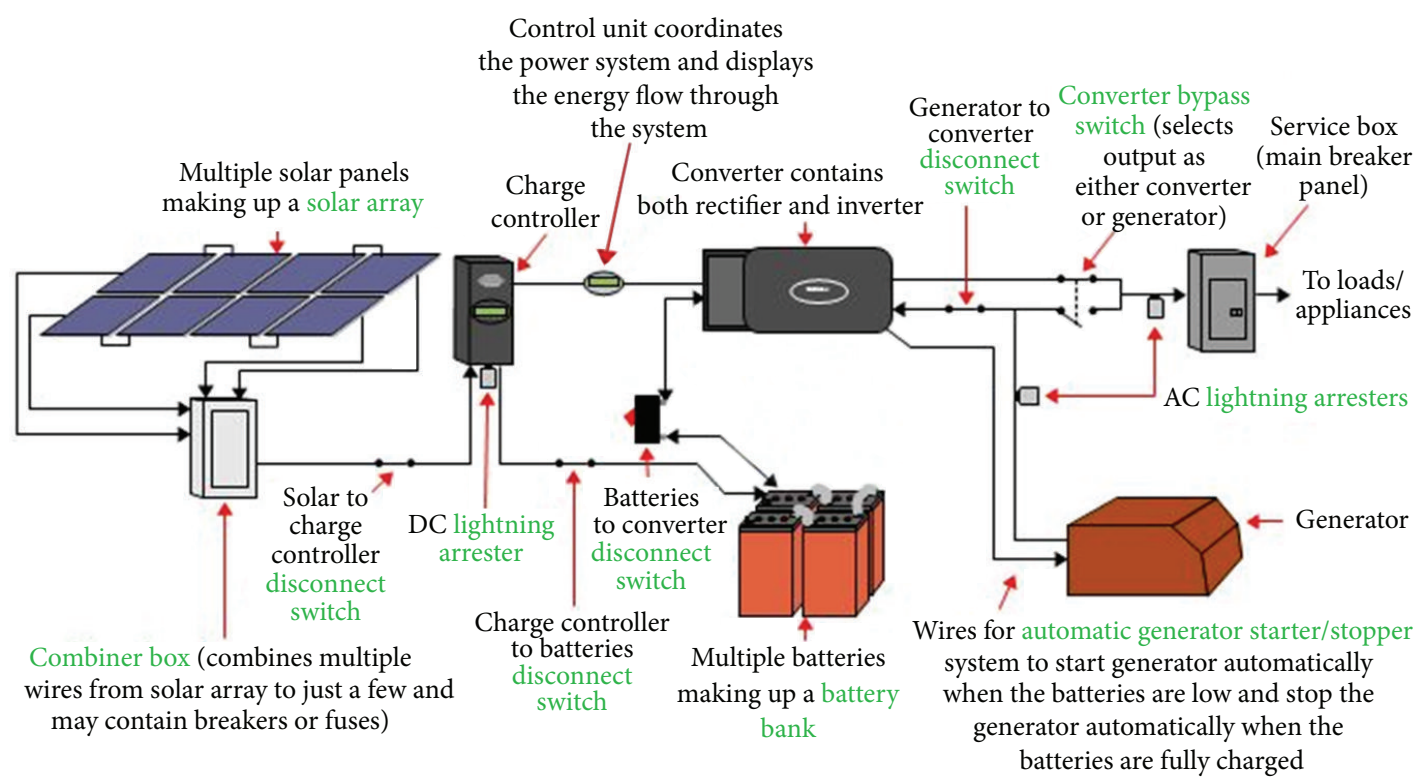

FIGURE 4: Photovoltaic hybrid power system structure [33].

TABLE 4: Results of each of the energy components of the hybrid system (PV and diesel) for electricity production, supply, and battery charging (kW).

\begin{tabular}{|c|c|c|c|c|c|c|}
\hline \multirow{2}{*}{ Month } & \multicolumn{3}{|c|}{$\begin{array}{l}\text { Electricity generated and supplied and battery } \\
\text { charge by the PV in hybrid system }(\mathrm{kW})\end{array}$} & \multicolumn{3}{|c|}{$\begin{array}{l}\text { Electricity generated and supplied and battery } \\
\text { charge by the diesel in hybrid system }(\mathrm{kW})\end{array}$} \\
\hline & $\begin{array}{l}\text { Electricity } \\
\text { generated }\end{array}$ & $\begin{array}{l}\text { Supplied to the load } \\
\text { via inverter }\end{array}$ & $\begin{array}{c}\text { Charging the } \\
\text { battery directly }\end{array}$ & $\begin{array}{l}\text { Electricity } \\
\text { generated }\end{array}$ & $\begin{array}{l}\text { Supplied to the } \\
\text { load directly }\end{array}$ & $\begin{array}{c}\text { Charging the } \\
\text { battery via rectifier }\end{array}$ \\
\hline January & 1538.295 & 987.628 & 239.282 & 1177.104 & 874.649 & 299.517 \\
\hline February & 1510.492 & 971.970 & 199.718 & 1016.936 & 724.017 & 289.982 \\
\hline March & 1705.644 & 1094.416 & 232.446 & 1096.767 & 792.623 & 301.472 \\
\hline April & 1554.395 & 1045.610 & 219.627 & 1074.702 & 781.803 & 289.705 \\
\hline May & 1488.347 & 1049.806 & 221.725 & 1143.499 & 826.317 & 314.101 \\
\hline June & 1333.962 & 936.894 & 215.577 & 1188.892 & 867.973 & 313.288 \\
\hline July & 1271.351 & 905.257 & 226.365 & 1273.178 & 955.024 & 314.666 \\
\hline August & 1230.539 & 845.398 & 226.867 & 1335.026 & 1004.386 & 324.882 \\
\hline September & 1343.075 & 892.323 & 217.040 & 1225.120 & 907.573 & 312.814 \\
\hline October & 1534.355 & 1051.274 & 216.828 & 1146.737 & 821.824 & 324.375 \\
\hline November & 1552.498 & 1023.349 & 224.026 & 1096.963 & 788.972 & 305.717 \\
\hline December & 1499.299 & 1015.452 & 227.093 & 1168.808 & 853.230 & 314.356 \\
\hline Total & 17562.252 & 11819.377 & 2666.594 & 13943.732 & 10198.391 & 3704.875 \\
\hline
\end{tabular}

3.1.2. Converter Cost (US\$ 0.320/Wp). The cost of a converter, based on prices cited by Nigerian suppliers, was US\$ 0.320/Wp [35].

3.1.3. Battery Cost (US $\$ 180 / \mathrm{kWh}$ ). The cost of a $6 \mathrm{~V} / 225 \mathrm{Ah}$ lead acid battery on the Nigerian market was found to be in the range of US\$ 172 [35]. Including balance of system (BOS) components and labour/installation costs, the capital cost for the battery arrays was adjusted upward to US\$180/kWh. The precise number of batteries required for each option is then determined by the simulation.

3.1.4. Generator Cost (US\$ 1000/kW). The capital cost of the genset includes the generator itself (usually diesel or gasoline), as well as BOS costs and labour/installation costs. On the Nigerian local market, a generator of smaller range 
(2-5 kVA) was priced at about US\$ 991 [36]. Including BOS and labour/installation costs, the total price was estimated at around US\$1,000 per kW load.

3.1.5. Fuel Cost (US\$1.2/L). The source for this estimate was the Nigerian official market rate as of October 2015.

3.1.6. Interest Rate: $7.5 \%$. Interest rates vary widely and can be particularly high in developing countries, having a profound impact on the cost-benefit assessment. Interest rates on Nigerian commercial bank loans may be between $6 \%$ and $7.5 \%$. An estimate of $7.5 \%$ was selected for this case study.

\section{Energy Losses in Stand-Alone PV/Diesel Hybrid Systems}

Stand-alone PV/diesel hybrid systems are designed to be totally self-sufficient in generating, storing, and supplying electricity to the electrical loads in remote areas. Figure 5 shows an energy flow diagram for a typical PV/diesel hybrid system. The following equation (23) shows the energy balance of a PV/diesel hybrid system:

$$
E_{\mathrm{IN}} \approx E_{\mathrm{OUT}} .
$$

The energy that has to be supplied from the generator can be determined as

$$
E_{\mathrm{MG}}=E_{\mathrm{LOAD}}+E_{\mathrm{LOSS}} \mathrm{R}-E_{\mathrm{PV}} .
$$

The energy that has to be supplied from the photovoltaic can be determined as

$$
E_{\mathrm{PV}}=E_{\mathrm{LOAD}}+E_{\mathrm{LOSS}} \mathrm{CC}+E_{\mathrm{LOSS}} \mathrm{B}+E_{\mathrm{LOSS}} \mathrm{I}-E_{\mathrm{MG}} .
$$

The objective of this study (efficient energy balance) is to minimize the energy that has to be supplied from auxiliary energy source (diesel generator) by the addition of PV panels. Additionally, the motor generator should be operated near its nominal power to achieve high fuel efficiency by the inclusion of battery bank. As shown in (24) and (25), energy losses are flowing into the energy demand and supply of the system; therefore, it is necessary to identify the energy losses in the system. A classification of all relevant energy losses in a stand-alone PV hybrid system is given as capture losses and system losses [37]. Capture losses account for the part of the incident radiation energy that remains uncaptured and which is therefore lost within a global energy balance. Capture or irradiation losses translate the fact that only part of the incoming irradiation is used for energy conversion. System losses define systematic energy losses that are due to the physical properties of the system components or the entire installation. Energy conversion losses constitute important contributions to this category [38].

System losses cover all energy losses which occur during the conversion of generated energy into usable AC electricity. In this study, only the energy conversion losses were considered, to assess the potential of the designed hybrid system. The losses are indicated in Figure 5.

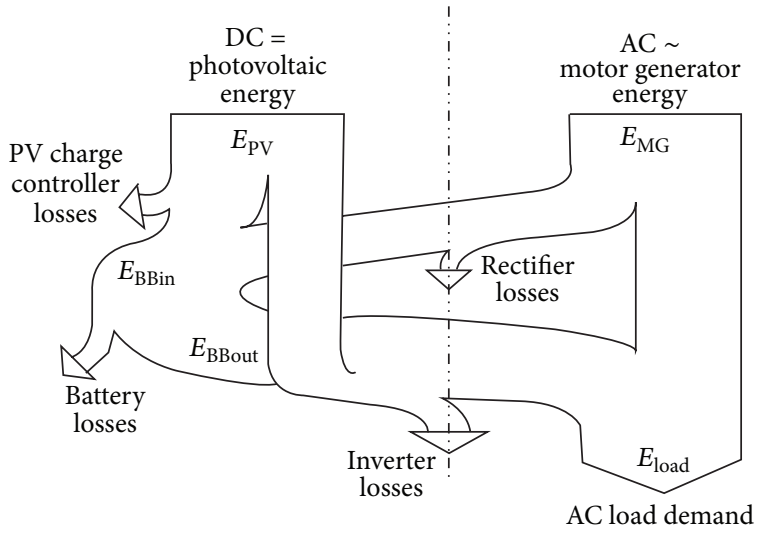

FIGURE 5: Energy flow diagram for a typical PV/diesel hybrid system [37].

\section{Results and Discussion}

The design provides an interesting example of how optimal combinations of photovoltaic and diesel generation with appropriate energy storage yielded multiple gains: a shift to renewable energy, a reliable supply for household energy needs, and lower overall cost of energy.

\subsection{Results}

5.1.1. Designed Hybrid System. To overcome the problem of the climatic changes, to ensure a reliable supply without interruption, and to improve the overall system efficiency, a hybrid system (that comprised a PV system, the diesel power system, and storage battery as backup sources) is essential as shown in Figure 4. The reasons for the inclusion of battery bank in this design are due to fluctuations in solar radiation and also for the generator to operate at optimum efficiency, because continued operation of generator at lower loads or severe variation in the load results in an inefficient engine performance and one of the options for the load management is to integrate battery bank (which becomes a load when charging to improve the generator efficiency) to improve the overall system efficiency. Considering various types and capacities of system devices (PV array, diesel generator, and battery size), the configurations which can meet the desired system reliability are obtained by changing the type and size of the devices systems. The configuration with the lowest LCE gives the optimal choice. Therefore, the optimal sizing of the hybrid system (PV-diesel generator-battery system) in terms of reliability, economy, and environment is shown in Tables 3 , 5 , and 6 , respectively. This was determined through rigorous mathematical computations.

From the design results, the PV power supply is between 8:00 $\mathrm{h}$ and 19:00 $\mathrm{h}$ while the radiation peak is between $12: 00 \mathrm{~h}$ and $14: 00 \mathrm{~h}$ as can be seen in the supplementary data. Between 12:00 $\mathrm{h}$ and 14:00 $\mathrm{h}$ there is no deficit in the system and the PV energy supplies the load and charges the battery, thereby reducing the operational hours of the diesel generator and the running cost of the hybrid energy 


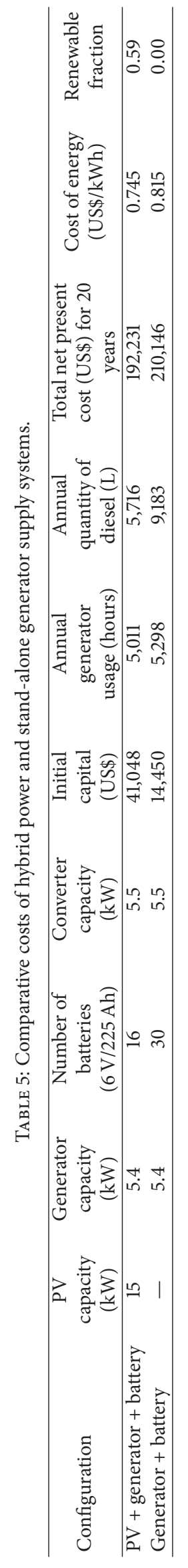


TABLE 6: Comparative emissions of hybrid power and stand-alone generator supply systems.

\begin{tabular}{lcccccccc}
\hline \multirow{2}{*}{ Configuration } & \multicolumn{4}{c}{ Pollutant emission $(\mathrm{kg} / \mathrm{yr})$} & \multicolumn{3}{c}{ Fuel consumption } & \multicolumn{2}{c}{ Operational hour of } \\
& $\mathrm{CO}_{2}$ & $\mathrm{CO}$ & $\mathrm{UHC}$ & $\mathrm{PM}$ & $\mathrm{SO}_{2}$ & $\mathrm{NO}_{x}$ & $(\mathrm{~L} / \mathrm{yr})$ & diesel generator (hr/yr) \\
\hline PV + generator + battery & 15,052 & 37.2 & 4.12 & 2.8 & 30.2 & 332 & 5,716 & 5,011 \\
Generator + battery & 24,183 & 59.7 & 6.61 & 4.5 & 48.6 & 533 & 9,183 & 5,298 \\
\hline
\end{tabular}

Note: PM refers to total particulate matter. UHC refers to unburned hydrocarbons.

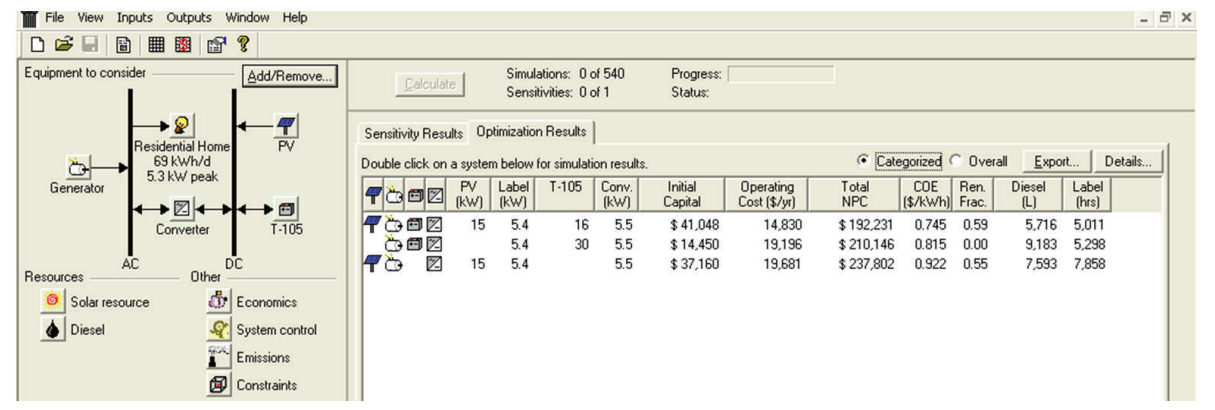

FIGURE 6: The optimization results from HOMER for hybrid PV/diesel energy system.

system as well as the pollutant emissions. There is likely to be deficit in other remaining hours due to poor radiation, and the deficit is being completed by either the battery or the diesel generator. The result of the demand met by the hybrid energy system (PV/diesel) over the course of the year is shown in the supplementary data; it shows how the sources were allocated according to the load demand and availability. It was observed that the variation is not only in the demand but also in the availability of solar resources. The battery or the diesel generator compensates the shortage depending on the decision mode.

5.1.2. Results from HOMER. The derivations from the developed software were compared to HOMER optimization method, and the same inputs used in calculations by the developed software were used by HOMER which produced the same results with the developed software as shown in Figure 6 (Figure 6 compared with Table 5). Therefore, the results from the software can be used as comparison and point of reference.

\subsection{Discussion}

5.2.1. Overall Energy Production and Utilization. From the design, solar power will not replace the need for diesel generator for this remote residential home but could offset a portion of the diesel fuel used. Although the residential loads provide the best possible match with PV output (since these loads typically peak during daytime and afternoon hours), there is still need for a backup with diesel generator (during the raining season and cloudy days).

In the solar resources, apart from the month of February that has 28 days, the month of March has the highest global and incident solar $\left(207.568 \mathrm{kWh} / \mathrm{m}^{2} ; 213.213 \mathrm{kWh} / \mathrm{m}^{2}\right)$, while the month of August has the least global and incident solar $\left(159.232 \mathrm{kWh} / \mathrm{m}^{2} ; 153.817 \mathrm{kWh} / \mathrm{m}^{2}\right)$ as shown in Table 7.
TABLE 7: Solar resources for the studied zone.

\begin{tabular}{lccc}
\hline Month & $\begin{array}{c}\text { Global solar } \\
\left(\mathrm{kWh} / \mathrm{m}^{2}\right)\end{array}$ & $\begin{array}{c}\text { Incident solar } \\
\left(\mathrm{kWh} / \mathrm{m}^{2}\right)\end{array}$ & $\begin{array}{c}\text { Power generated } \\
\text { with 15 kW PV } \\
\text { array }(\mathrm{kW})\end{array}$ \\
\hline January & 173.783 & 192.285 & 1538.295 \\
February & 176.292 & 188.814 & 1510.492 \\
March & 207.568 & 213.213 & 1705.644 \\
April & 198.460 & 194.312 & 1554.395 \\
May & 197.020 & 186.037 & 1488.347 \\
June & 178.982 & 166.744 & 1333.962 \\
July & 168.215 & 158.916 & 1271.351 \\
August & 159.232 & 153.817 & 1230.539 \\
September & 166.994 & 167.880 & 1343.075 \\
October & 182.472 & 191.792 & 1534.355 \\
November & 175.089 & 194.054 & 1552.498 \\
December & 165.744 & 187.409 & 1499.299 \\
\hline Total & 2149.851 & 2195.273 & 17562.252 \\
\hline
\end{tabular}

In the hybrid system configuration, the sizing was done in favour of PV system (to overcome the problem of the climatic changes), and in order to accommodate the load demand for all the months, excess electricity was generated by the PV system. The excess electricity generated differs from month to month and depends on the incident solar. The highest excess electricity is observed in March $(381.30 \mathrm{~kW})$, while the least is in the months of July $(143.05 \mathrm{~kW})$ and August $(163.868 \mathrm{~kW})$, the two months most affected by raining season.

In the month of March, the PV generated the highest electricity (1705.644 kW) and supplied to the load via inverter the highest electricity $(1094.416 \mathrm{~kW})$. This was because the month of March has the highest global and incident solar $\left(207.568 \mathrm{kWh} / \mathrm{m}^{2} ; 213.213 \mathrm{kWh} / \mathrm{m}^{2}\right)$, while in the month of August, the PV generated the least electricity $(1230.539 \mathrm{~kW})$ 
and supplied to the load via inverter the least electricity $(845.398 \mathrm{~kW})$ and this was due to least global and incident solar $\left(159.232 \mathrm{kWh} / \mathrm{m}^{2} ; 153.817 \mathrm{kWh} / \mathrm{m}^{2}\right)$. In this month of August, to ensure a reliable supply without interruption, the diesel due to the low electricity generated by the PV (caused by low incident solar) supplies to the load the highest electricity $(1004.386 \mathrm{~kW})$ and charges the battery via rectifier (to improve the overall system efficiency). In the month of August, battery charging $(503.078 \mathrm{~kW})$ and discharging $(-425.589 \mathrm{~kW})$ are highest due to low supply coming from the $\mathrm{PV}$. The generator becomes $\mathrm{ON}$ often to serve the ACload and at the same time charge the battery (which is a DC load; battery becomes a load when charging). It is worthwhile noting from Table 3 that the PV-diesel hybrid solution supported by battery storage produces $17,562 \mathrm{kWh} / \mathrm{yr}$ (59\%) from solar PV array and $13,944 \mathrm{kWh} / \mathrm{yr}(41 \%)$ from diesel generator making a total of $31,506 \mathrm{kWh} / \mathrm{yr}(100 \%)$.

5.2.2. Energy Flows. One of the main objectives of this study was to produce a detailed experimental accounting of energy flows through the hybrid system. In particular, my interest is in quantifying all system losses.

Hybrid PV/Diesel System with Battery. For the PV part of the hybrid system, device losses include PV charge controller losses, DC-AC conversion losses, both for energy flowing directly to the load and for energy transiting through the battery, and storage round-trip losses. On the generator side, the AC-DC conversion losses affect electrical energy that does not flow directly to the load. The reason for these losses on the generator side is that the hybrid system was designed to be cycle charging meaning that the diesel generator is allowed to charge the battery. follows:

All losses through the hybrid system are classified as

(i) PV charge controller losses.

(ii) Battery storage losses.

(iii) Rectifier (battery charger conversion) losses.

(iv) Inverter losses.

PV charge controller losses are due to the DC/DC conversion efficiency (converting energy generated by the PV to charge the storage battery). DC/DC conversion losses are generated during the control of the flow of current to and from the battery by the PV charge controller. Result shows that the losses are minimal when compared to other component losses (storage losses, inverter, and rectifier losses) as shown in Table 3.

Storage losses comprise all energy losses within a battery. They are described by the charge and discharge efficiencies of the battery as well as the self-discharge characteristics. In the month of August, the battery charging and the discharging as well as its losses (due to charge and discharge efficiencies) are highest due to the fact that diesel becomes $\mathrm{ON}$ often to charge the battery; when the battery reaches its maximum point of charge, the diesel stops while the battery starts discharging in order to power the load, and once the battery reaches its minimum point of discharge, it stops discharging and the diesel comes ON again. The process continues the same way until the PV starts to generate electricity to supply it to the load and charge the battery; otherwise, it returns to the diesel charging the battery. Results of the design show that the storage battery was charged with $227.093 \mathrm{kWh} / \mathrm{yr}$ and $314.356 \mathrm{kWh} / \mathrm{yr}$ by the PV and diesel system, respectively, making a total charge of $5816.474 \mathrm{kWh} / \mathrm{yr}$, while the battery discharged (supplied) to the load via the inverter a total discharge of $-4953.761 \mathrm{kWh} / \mathrm{yr}$, having losses of $862.713 \mathrm{kWh} / \mathrm{yr}$ as shown in Tables 3 and 4.

Battery charger conversion losses are due to the rectifier's $\mathrm{AC} / \mathrm{DC}$ efficiency. AC/DC conversion losses are generated during battery charging from an $\mathrm{AC}$ source. In the month of August, the rectifier receives the highest electricity from the diesel generator due to the month's least global and incident solar $\left(159.232 \mathrm{kWh} / \mathrm{m}^{2} ; 153.817 \mathrm{kWh} / \mathrm{m}^{2}\right)$ and this affects the production from the PV; at this point the diesel comes ON in order to ensure a reliable supply without interruption. Results of the design show that the rectifier was supplied with $3704.875 \mathrm{kWh} / \mathrm{yr}$ and rectified to the battery with $3149.880 \mathrm{kWh} / \mathrm{yr}$, having losses of $554.995 \mathrm{kWh} / \mathrm{yr}$ as shown in Tables 3 and 4.

Inverter losses are due to the inverter's DC/AC efficiency. $\mathrm{DC} / \mathrm{AC}$ inverter losses occur before the initially provided energy can be consumed by an AC load. It means that all electrical energy that does not flow directly to the AC load passes through the inverter such as electricity flowing from the PV system, electricity rectified to the battery, and the one coming from the battery. In the month of August, the inverter receives the least electricity from the PV and battery due to the month's least global and incident solar $\left(159.232 \mathrm{kWh} / \mathrm{m}^{2}\right.$; $\left.153.817 \mathrm{kWh} / \mathrm{m}^{2}\right)$. Although the battery receives the highest charging of $503.078 \mathrm{~kW}$ from both the PV $(226.867 \mathrm{~kW})$ and diesel (rectified to the battery with $276.211 \mathrm{~kW}$ ), the inverter still receives the least electricity because the diesel comes often to supply the AC load and charge the battery; the charging of the battery by the rectifier shows how often diesel supplies electricity to the load in this month of August as shown in Tables 3 and 4.

In conclusion, while the DC/DC conversion efficiency is generally low, the AC/DC rectifier (battery charger conversion) efficiency is somewhat lower than the DC/AC inverter efficiency as shown in Table 3.

5.2.3. Economic Costs. The capital cost of a PV/diesel hybrid solution with batteries is nearly three times higher than that of a generator and battery combination (US $\$ 41,048$ ), but the net present cost, representing cost over the lifetime of the system, is less than one-half of the generator and battery combination (US\$ 192,231), as shown in Table 5. The net present cost (NPC) of the PV/diesel/battery hybrid system is slightly lower than the NPC of the diesel/battery combination as a result of less fuel consumption and because fewer storage batteries are needed, and replacing batteries is a significant factor in system maintenance.

5.2.4. Environmental Pollution. On the environmental impact perspective, an increase in the operational hours of diesel generator brings about increase in the fuel 
consumption as well as an increase in GHG emission, whereas a reduction in the operational hours of diesel generator brings about reduction in the fuel consumption, thereby a reduction in GHG emission. Diesel system operates for 5,298 h/annum, has a fuel consumption of 9,183 L/annum, and generates in kilogrammes $(\mathrm{kg})$ the pollutant emissions as shown in Table 6, while in the hybrid PV-diesel system, diesel generator operates for $5,011 \mathrm{~h} /$ annum, has a fuel consumption of 5,716 L/annum, and emits in kilogrammes the pollutant emissions annually into the atmosphere of the location of the residence as shown in Table 6 . Reducing fuel consumption also means less emission from the energy system as shown by the solar PV-diesel system which has the lowest pollutant emissions.

\section{Conclusion}

This paper investigates the designing of a stand-alone hybrid power system focusing on photovoltaic/diesel energy system with energy storage in batteries. Starting from the analysis of the models of the system components, a complete simulation model is realized. From the designed system, a detailed experimental accounting of energy flows through the hybrid system was produced and all system losses caused by PV charge controller, battery storage round-trip, rectifier, and inverter conversions were quantified and documented. Results show that PV charge controller losses are due to the DC/DC conversion efficiency and are generated during the control of the flow of current to and from the battery by the PV charge controller, while storage losses comprise all energy losses within a battery and are described by the charge and discharge efficiencies of the battery as well as the self-discharge characteristics. In addition, battery charger conversion losses are due to the rectifier's AC/DC efficiency and are generated during battery charging from an $\mathrm{AC}$ source, while inverter losses are due to the inverter's DC/AC efficiency and occur before the initially provided energy can be consumed by an AC load. From the results, it has proven that the DC/DC conversion efficiency is generally low, while the $\mathrm{AC} / \mathrm{DC}$ rectifier efficiency is somehow lower than the $\mathrm{DC} / \mathrm{AC}$ inverter efficiency. Also, it has been demonstrated that the use of hybrid PV/diesel system with battery (one unit of $15 \mathrm{~kW}$ PV array, one unit of $5.4 \mathrm{~kW}$ generator, with 16 units of battery) can significantly reduce the dependence on solely available diesel resource. The designed hybrid system minimizes diesel operational hour and thereby reduces the fuel consumption which significantly affects (reduces) the pollution, such as carbon emission, thus reducing the greenhouse effect. Although utilization of hybrid PV/diesel system with battery might not significantly reduce the total NPC and COE, it has been able to cut down the dependence on diesel. On the other hand, it was also proven that the use of hybrid $\mathrm{PV} /$ diesel system with battery would be more economical if the price of diesel increased significantly. With a projection period of 20 years and $7.5 \%$ annual real interest rate, it was found that the use of hybrid PV/diesel system with battery could achieve significantly lower NPC and COE as compared to a stand-alone diesel system. As a conclusion, the hybrid $\mathrm{PV} /$ diesel system has potential use in replacing or upgrading existing stand-alone diesel systems in Nigeria.

\section{Nomenclature}

\begin{tabular}{|c|c|}
\hline A: & The surface area in $\mathrm{m}^{2}$ \\
\hline$C_{\text {acap }, c}:$ & Annualized capital cost of a component \\
\hline$C_{\text {arep }, c}:$ & $\begin{array}{l}\text { Annualized replacement cost of a } \\
\text { component }\end{array}$ \\
\hline$C_{\mathrm{aop}, c}:$ & Annualized operating cost of a component \\
\hline & Annualized capital cost of solar power \\
\hline$C_{\text {arep }, s}:$ & $\begin{array}{l}\text { Annualized replacement cost of solar } \\
\text { power }\end{array}$ \\
\hline$C_{\mathrm{aop}, s}:$ & Annualized operating cost of solar power \\
\hline & Annualized capital cost of diesel generator \\
\hline$C_{\text {arep }, g}:$ & $\begin{array}{l}\text { Annualized replacement cost of diesel } \\
\text { generator }\end{array}$ \\
\hline$C_{\mathrm{aop}, g}:$ & $\begin{array}{l}\text { Annualized operating cost of diesel } \\
\text { generator }\end{array}$ \\
\hline$C_{\mathrm{af}, g}:$ & Annualized fuel cost for diesel generator \\
\hline$C_{\text {acap }, b}:$ & Annualized capital cost of batteries power \\
\hline$C_{\text {arep }, b}:$ & $\begin{array}{l}\text { Annualized replacement cost of batteries } \\
\text { power }\end{array}$ \\
\hline$C_{\mathrm{aop}, b}:$ & $\begin{array}{l}\text { Annualized operating cost of batteries } \\
\text { power }\end{array}$ \\
\hline$C_{\text {acap }, c}:$ & Annualized capital cost of converter power \\
\hline$C_{\text {arep }, c}:$ & $\begin{array}{l}\text { Annualized replacement cost of converter } \\
\text { power }\end{array}$ \\
\hline$C_{\text {aop }, c}:$ & alized operating cost of converter \\
\hline$C_{\text {cap }}:$ & Initial capital cost of the component \\
\hline$c_{\mathrm{CO}_{2}}:$ & nissions of carbon dioxide \\
\hline$c_{\mathrm{CO}}:$ & $\begin{array}{l}\text { Cost for emissions of carbon monoxide } \\
(\mathrm{CO})(\$ / \mathrm{t})\end{array}$ \\
\hline$c_{\mathrm{UHC}}:$ & $\begin{array}{l}\text { missions of unburned } \\
\text { ons (UHC) }(\$ / t)\end{array}$ \\
\hline$c_{\mathrm{PM}}:$ & $\begin{array}{l}\text { Cost for emissions of particulate matter } \\
(\mathrm{PM})(\$ / \mathrm{t})\end{array}$ \\
\hline$c_{\mathrm{SO}_{2}}:$ & $\begin{array}{l}\text { Cost for emissions of sulfur oxide }\left(\mathrm{SO}_{2}\right) \\
(\$ / \mathrm{t})\end{array}$ \\
\hline$c_{\mathrm{NO}_{x}}:$ & $\begin{array}{l}\text { Cost for emissions of nitrogen oxide } \\
\left(\mathrm{NO}_{x}\right)(\$ / \mathrm{t})\end{array}$ \\
\hline$C_{\mathrm{oc}}(t):$ & The cost of operating component \\
\hline & Replacement cost of the component \\
\hline $\operatorname{CRF}\left(i, R_{\text {proj }}\right):$ & Capital recovery factor \\
\hline$E_{\mathrm{BAT}}(t-1):$ & $\begin{array}{l}\text { The energy stored in battery at hour } t-1 \text {, } \\
\text { kWh }\end{array}$ \\
\hline$E_{\text {Needed }}(t):$ & $\begin{array}{l}\text { The hourly load demand or energy needed } \\
\text { at a particular period of time }\end{array}$ \\
\hline$E_{\mathrm{REC}-\mathrm{OUT}}(t):$ & $\begin{array}{l}\text { The hourly energy output from rectifier, } \\
\text { kWh }\end{array}$ \\
\hline$E_{\mathrm{REC}-\mathrm{IN}}(t):$ & The hourly energy input to rectifier, kWh \\
\hline$E_{\text {SUR-AC }}(t):$ & $\begin{array}{l}\text { The amount of surplus energy from AC } \\
\text { sources, kWh }\end{array}$ \\
\hline$E_{\mathrm{DEG}}(t):$ & $\begin{array}{l}\text { The hourly energy generated by diesel } \\
\text { generator }\end{array}$ \\
\hline$E_{\mathrm{PVG}-\mathrm{IN}}(t):$ & $\begin{array}{l}\text { The hourly energy output from inverter } \\
\text { (in case of SPV), kWh }\end{array}$ \\
\hline$E_{\mathrm{PVG}}(t):$ & The hourly energy output of the PV \\
\hline
\end{tabular}

$C_{\text {acap }, c}: \quad$ Annualized capital cost of a component

$C_{\text {arep }, c}: \quad$ Annualized replacement cost of a

$C_{\text {acap }, s}$ :

$C_{\text {aop,s: }}$

$C_{\text {acap }, g}$

Cops.

Annualized

generator

$C_{\mathrm{af}, g}:$

$C_{\text {acap }, b}:$

Annualized capital cost of batteries power

power

power

$C_{\text {acap }, c}:$

Annualized capital cost of converter power

Annualized replacement cost of converter

power

$\left(\mathrm{CO}_{2}\right)(\$ / \mathrm{t})$

(CO) $(\$ / t)$

hydrocarbons (UHC) ( $\$ / \mathrm{t})$

(PM) $(\$ / \mathrm{t})$

$(\$ / t)$

$\left(\mathrm{NO}_{x}\right)(\$ / \mathrm{t})$

$C_{\text {oc }}(t):$

$C_{\text {rep }}$ :

$\operatorname{CRF}\left(i, R_{\text {proj }}\right)$ : Capital recovery factor

$E_{\mathrm{BAT}}(t-1)$ : The energy stored in battery at hour $t-1$, kWh

at a particular period of time

$E_{\mathrm{REC}-\mathrm{N}}(t): \quad$ The hourly energy input to rectifier, $\mathrm{kWh}$

$E_{\text {SUR-AC }}(t)$ : The amount of surplus energy from AC sources, kWh

$E_{\mathrm{DEG}}(t): \quad$ The hourly energy generated by diesel generator

(in case of SPV), kWh generator 
$E_{\text {BAT-INV }}(t)$ : The hourly energy output from inverter (in case of battery), kWh

$E_{\mathrm{BAT}}(t-1)$ : The energy stored in battery at hour $t-1$, kWh

$E_{\text {LOAD }}(t)$ : The hourly energy consumed by the load side, kWh

$E_{\text {CC-OUT }}(t)$ : The hourly energy output from charge controller, kWh

$E_{\text {CC-IN }}(t)$ The hourly energy input to charge controller, kWh

$E_{\text {REC-OUT }}(t)$ : The hourly energy output from rectifier, kWh

$E_{\text {SUR-DC }}(t)$ : The amount of surplus energy from DC source (PV panels), kWh

$E_{\mathrm{BAT}}(t): \quad$ The energy stored in battery at hour $t$, $\mathrm{kWh}$

$E_{\mathrm{IN}}: \quad$ Is equal to $E_{\mathrm{PV}}+E_{\mathrm{MG}}$

$E_{\text {OUT }}$ :

$E_{\mathrm{PV}}$ :

$E_{\mathrm{MG}}$ :

$E_{\text {LOAD }}$ :

$E_{\text {LOSS }}$ :

$E_{\mathrm{LOSS}} \mathrm{CC}$ :

$E_{\mathrm{LOSS}} \mathrm{B}$ :

$E_{\mathrm{LOSS}} \mathrm{R}$ :

$E_{\text {LOSS }}$ :

$G(t)$ :

$i$ :

INT( ):

$M_{\mathrm{CO}_{2}}$ :

$\mathrm{M}_{\mathrm{CO}}$ :

$M_{\mathrm{NO}_{x}}$ :

$M_{\mathrm{PM}}$ :

$M_{\mathrm{SO}_{2}}$ :

$M_{\mathrm{UHC}}$ :

$N$ :

$P$ :

$R_{\text {proj }}$ :

$R_{\text {comp }}$ :

SFF( ):

$\eta_{\mathrm{PVG}}$ :

$\eta_{\mathrm{DEG}}:$

$\eta_{\text {REC }}:$

$\eta_{\mathrm{INV}}:$

$\eta_{\mathrm{DCHG}}:$

$\eta_{\mathrm{CC}}:$

$\eta_{\mathrm{CHG}}:$ Is equal to $E_{\mathrm{LOAD}}+E_{\mathrm{LOSS}}$ Energy generated by the PV array (kWh) Energy generated by the motor generator (kWh) Energy supplied to the load (kWh) Energy losses (kWh), which comprise all $\left(E_{\mathrm{LOSS}} \mathrm{CC}+E_{\mathrm{LOSS}} \mathrm{B}+E_{\mathrm{LOSS}} \mathrm{R}+E_{\mathrm{LOsS}} \mathrm{I}\right)$ Energy losses via charge controller (kWh) Energy losses via battery (kWh) Energy losses via rectifier (kWh) Energy losses via inverter (kWh) The hourly irradiance in $\mathrm{kWh} / \mathrm{m}^{2}$ Interest rate The integer function, returning the integer portion of a real value

Annual emissions of $\mathrm{CO}_{2}(\mathrm{~kg} / \mathrm{yr})$

Annual emissions of CO (kg/yr)

Annual emissions of $\mathrm{NO}_{x}(\mathrm{~kg} / \mathrm{yr})$

Annual emissions of particulate matter (PM) (kg/yr)

Annual emissions of $\mathrm{SO}_{2}(\mathrm{~kg} / \mathrm{yr})$

Annual emissions of unburned

hydrocarbons (UHC) (kg/yr)

Number of years

The PV penetration level factor

Project lifetime

Lifetime of the component

Sinking fund factor

The efficiency of PV generator

The diesel generator efficiency

The efficiency of rectifier

The efficiency of inverter

The battery discharging efficiency

The efficiency of charge controller The battery charging efficiency.

\section{References}

[1] M. Jovanović, "An analytical method for the measurement of energy systems sustainability in urban areas," FME Transactions, vol. 36, no. 4, pp. 157-166, 2008.

[2] National Aeronautics and Space Administration (NASA) Atmospheric Science Data Center, 2015, http://eosweb.larc.nasa .gov/sse/2012.

[3] V. A. Ani, Energy optimization at GSM base station sites located in rural areas [Ph.D. thesis], 2015, http://www.unn.edu.ng/ publications/files/17774_ENERGY_OPTIMIZATION_AT_GSM_ BASE_STATION_SITES_LOCATED_IN_RURAL_AREAS.pdf.

[4] B. S. Borowy and Z. M. Salameh, "Optimum photovoltaic array size for a hybrid wind/PV system," IEEE Transactions on Energy Conversion, vol. 9, no. 3, pp. 482-488, 1994.

[5] R. Dufo-López and J. L. Bernal-Agustín, "Design and control strategies of PV-diesel systems using genetic algorithms," Solar Energy, vol. 79, no. 1, pp. 33-46, 2005.

[6] I. Gross, “The cost of diesel for Africa's mobile operators: 2012 may be the year that this bird comes home to roost," November 2011, http://www.balancingact-africa.com/news/en/issue-no581.

[7] M. A. Elhadidy, "Performance evaluation of hybrid (wind/solar/ diesel) power systems," Renewable Energy, vol. 26, no. 3, pp. 401413, 2002.

[8] W. Kellogg, M. H. Nehrir, G. Venkataramanan, and V. Gerez, "Optimal unit sizing for a hybrid wind/photovoltaic generating system," Electric Power Systems Research, vol. 39, no. 1, pp. 35-38, 1996.

[9] M. A. Elhadidy and S. M. Shaahid, "Role of hybrid (wind + diesel) power systems in meeting commercial loads," Renewable Energy, vol. 29, no. 1, pp. 109-118, 2004.

[10] M. T. Iqbal, "Simulation of a small wind fuel cell hybrid energy system," Renewable Energy, vol. 28, no. 4, pp. 511-522, 2003.

[11] M. H. Nehrir, B. J. LaMeres, G. Venkataramanan, V. Gerez, and L. A. Alvarado, "An approach to evaluate the general performance of stand-alone wind/photovoltaic generating systems," IEEE Transactions on Energy Conversion, vol. 15, no. 4, pp. 433439, 2000.

[12] S. H. Karaki, R. B. Chedid, and R. Ramadan, "Probabilistic performance assessment of autonomous solar-wind energy conversion systems," IEEE Transactions on Energy Conversion, vol. 14, no. 3, pp. 766-772, 1999.

[13] C. Protogeropoulos, B. J. Brinkworth, and R. H. Marshall, "Sizing and techno-economical optimization for hybrid solar photovoltaic/wind power systems with battery storage," International Journal of Energy Research, vol. 21, no. 6, pp. 465-479, 1997.

[14] L. L. Bucciarelli Jr., "Estimating loss-of-power probabilities of stand-alone photovoltaic solar energy systems," Solar Energy, vol. 32, no. 2, pp. 205-209, 1984.

[15] S. A. Klein and W. A. Beckman, "Loss-of-load probabilities for stand-alone photovoltaic systems," Solar Energy, vol. 39, no. 6, pp. 499-512, 1987.

[16] L. Barra, S. Catalanotti, F. Fontana, and F. Lavorante, "An analytical method to determine the optimal size of a photovoltaic plant," Solar Energy, vol. 33, no. 6, pp. 509-514, 1984.

\section{Competing Interests}

The author declares no competing interests.
[17] B. Bartoli, V. Cuomo, F. Fontana, C. Serio, and V. Silvestrini, "The design of photovoltaic plants: an optimization procedure," Applied Energy, vol. 18, no. 1, pp. 37-47, 1984. 
[18] L. L. Bucciarelli Jr., "The effect of day-to-day correlation in solar radiation on the probability of loss-of-power in a stand-alone photovoltaic energy system," Solar Energy, vol. 36, no. 1, pp. 1114, 1986.

[19] P. P. Groumpos and G. Papageorgiou, "An optimal sizing method for stand-alone photovoltaic power systems," Solar Energy, vol. 38, no. 5, pp. 341-351, 1987.

[20] V. A. Graham, K. G. T. Hollands, and T. E. Unny, "A time series model for $K_{t}$ with application to global synthetic weather generation," Solar Energy, vol. 40, no. 2, pp. 83-92, 1988.

[21] R. J. Aguiar, M. Collares-Pereira, and J. P. Conde, "Simple procedure for generating sequences of daily radiation values using a library of Markov transition matrices," Solar Energy, vol. 40, no. 3, pp. 269-279, 1988.

[22] R. N. Chapman, "Development of sizing nomograms for standalone photovoltaic/storage systems," Solar Energy, vol. 43, no. 2, pp. 71-76, 1989.

[23] R. N. Chapman, "The synthesis of solar radiation data for sizing stand-alone photovoltaic systems," in Proceedings of the 21st IEEE Photovoltaic Specialists Conference, pp. 965-970, Orlando, Fla, USA, May 1990.

[24] I. Abouzahr and R. Ramakumar, "Loss of power supply probability of stand-alone photovoltaic systems: a closed form solution approach," IEEE Transactions on Energy Conversion, vol. 6, no. 1, pp. 1-11, 1991.

[25] A. Mellit, "Sizing of photovoltaic systems: a review," Revue des Energies Renouvelables, vol. 10, no. 4, pp. 463-472, 2007.

[26] A. Gupta, R. P. Saini, and M. P. Sharma, "Steady-state modelling of hybrid energy system for off grid electrification of cluster of villages," Renewable Energy, vol. 35, no. 2, pp. 520-535, 2010.

[27] S. Ashok, "Optimised model for community-based hybrid energy system," Renewable Energy, vol. 32, no. 7, pp. 1155-1164, 2007.

[28] D. K. Lal, B. B. Dash, and A. K. Akella, "Optimization of PV/ Wind/Micro-Hydro/diesel hybrid power system in homer for the study area," International Journal on Electrical Engineering and Informatics, vol. 3, no. 3, pp. 307-325, 2011.

[29] K. Sopian, A. Zaharim, Y. Ali, Z. M. Nopiah, J. A. B. Razak, and N. S. Muhammad, "Optimal operational strategy for hybrid renewable energy system using genetic algorithms," WSEAS Transactions on Mathematics, vol. 7, no. 4, pp. 130-140, 2008.

[30] H. Abdolrahimi and H. K. Karegar, "Optimization and sensitivity analysis of a hybrid system for a reliable load supply in KISH_IRAN," International Journal of Advanced Renewable Energy Research, vol. 1, no. 4, pp. 33-41, 2012.

[31] T. Lambert, P. Gilman, and P. Lilienthal, "Micropower system modeling with HOMER," in Integration of Alternative Sources of Energy, F. A. Farret and M. G. Simões, Eds., chapter 15, John Wiley \& Sons, New York, NY, USA, 2006.

[32] V. A. Graham and K. G. T. Hollands, "A method to generate synthetic hourly solar radiation globally," Solar Energy, vol. 44, no. 6, pp. 333-341, 1990.

[33] Off grid solar power system, 2016, http://rimstar.org/renewnrg/ off_grid_solar_power_systems.htm.

[34] Solar Power Systems Components-Solar Panels Prices in Nigeria, http://www.naijatechguide.com/2008/11/solar.

[35] The Solar Shop Ltd, 2016, http://www.solarshopnigeria.com/.

[36] Tiger Generators Model Prices, Nigeria Technology Guide, 2015, https://www.naijatechguide.com/2008/03/tiger-generatorsnigeria.html.
[37] S. Beverngen, Mini Grid Kit Report EMS Strategy Review, University of Kassel, Kassel, Germany, 2002.

[38] D. Mayer and M. Heidenreich, "Performance analysis of stand alone PV systems from a rational use of energy point of view," in Proceedings of the 3rd World Conference on Photovoltaic Energy Conversion, pp. 2155-2158, IEEE, Osaka, Japan, May 2003. 

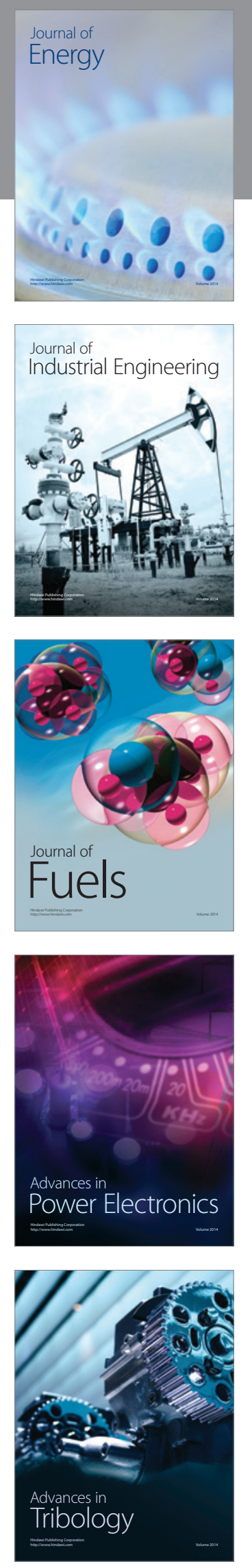
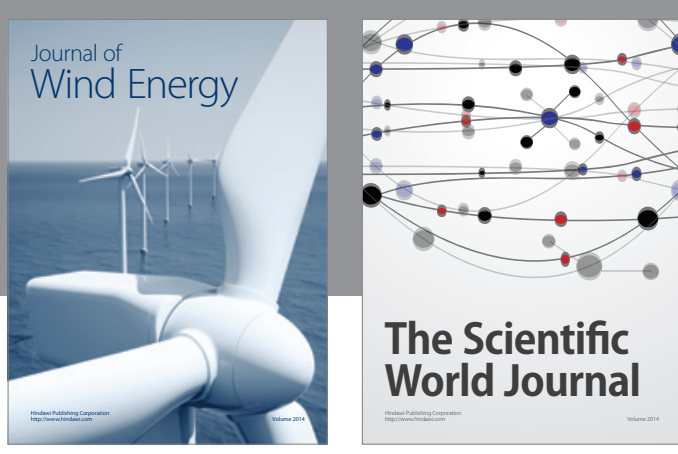

The Scientific World Journal
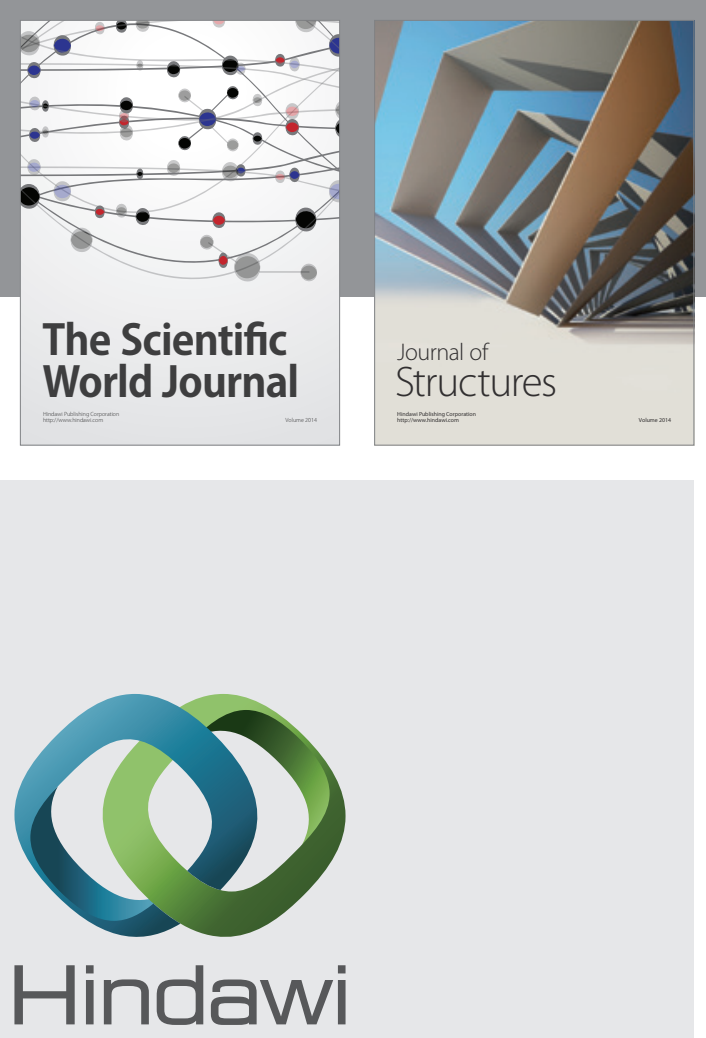

Submit your manuscripts at

http://www.hindawi.com
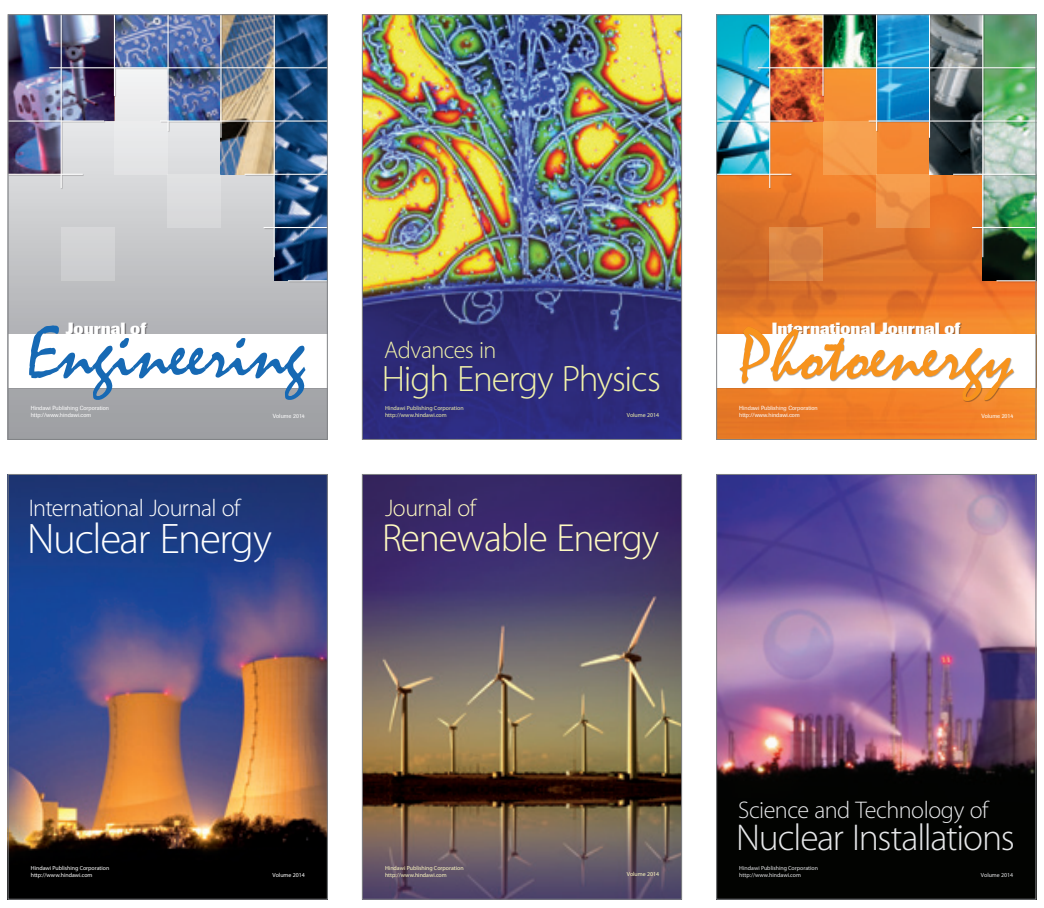
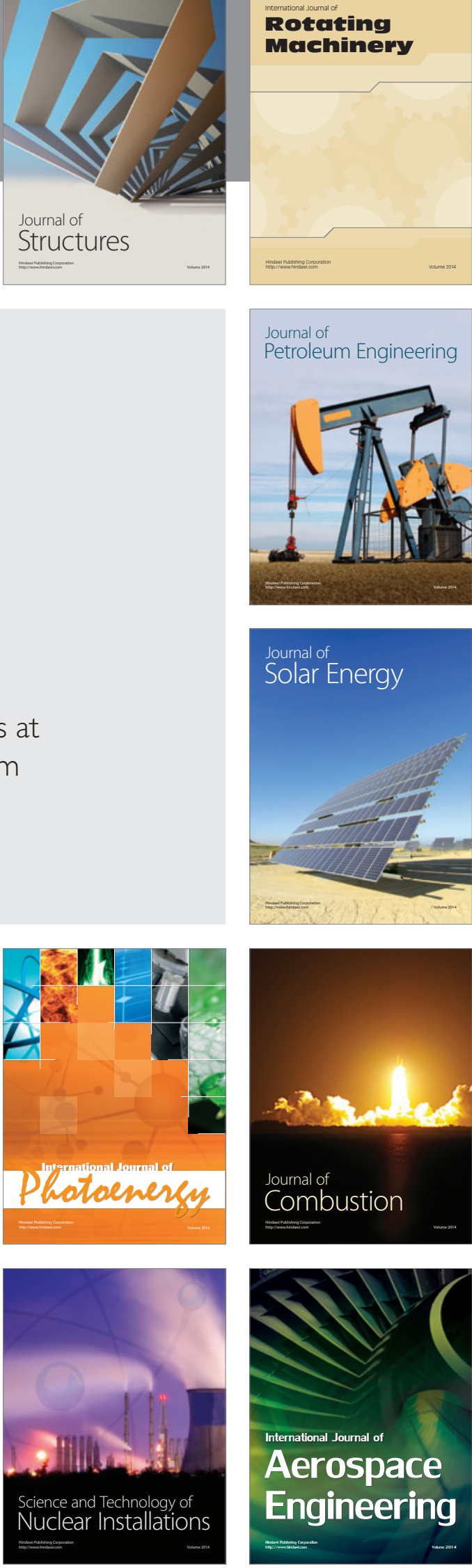